\title{
BRINCADEIRAS ANTIGAS
}

Antigamente não existiam muito brinquedos e se as crianças quisessem se divertir tinham que usar a criatividade. As brincadeiras antigas para crianças mais famosas eram: Amarelinha, bolinha de gude, cantigas de roda, passa anel, roda pião, pipa... Tudo isso fazia parte do seu cotidiano e assim elas se divertiam por horas e dias.

Brincadeiras Antigas - Pião

(imagem retirada de pesquisa google images - origem www .pca.org.br/imagens/robson/03piao.jpg)

Mas hoje as crianças não devem nem saber o que são essas brincadeiras. A tecnologia transformou o mundo deles e trouxe a tona brinquedos que não exigem criatividade, muito menos esforço.

Se você quer que seus filhos retomem as brincadeiras do passado, nada melhor do que tirar algum tempo e ensinar para eles que para brincar não é preciso gastar. Uma boa opção é ensinar para eles as brincadeiras que você mais gostava e assim também brincar junto com eles. Se não lembra mais ou está sem ideia, algumas dicas para ajudar:

- Cinco Marias - é preciso achar 5 pedrinhas de mesmo tamanho ou até mesmo saquinhos feitos com arroz ou areia. Jogue todas as pedrinhas no chão e tire uma delas, depois com a mesma mão jogue para o alto e pegue uma das que ficaram no chão. Faça isso até ter pegado todas. $\mathrm{Na}$ segunda rodada ao invés de pegar uma por vez, pegue duas. Na terceira rodada você pega três ao mesmo tempo e na última rodada você pega todas de uma vez só.

- Roda - forme uma roda e cante cantigas antigas, como pau no gato, ciranda-cirandinha, a canoa virou, pirulito que bate bate, samba lelê, se esta rua fosse minha, serra serra serrador, etc. 
- Escravos de Jó - Duas pessoas cantam a música (escravos de jó, jogavam caxangá, tira, põe, deixa ficar, guerreiros com guerreiros fazem zigue, zigue zá). Cada um com uma pedrinha ou um bombom na mão e vai seguindo o que diz a música.

- Amarelinha: faça um risco no chão e numere de 1 a 10, no ultimo faça um arco representando o céu. Pule com um pé só dentro de cada quadrado, sem errar.

- Batata quente- As pessoas ficam em círculo e alguém fica de fora. Passem uma bola bem rápida de mão em mão e quem estiver fora diz: "batata quente, quente, quente, ..., queimou!", em quem a bola parar no queimou é eliminado.

Adoletá

A-do-le-tá

Le-pe-ti

Pe-ti-pe-tá

Le café com chocolá

A-do-le-tá

Os componentes fazem formação de roda, onde se desloca a mão direita de forma a bater com a palma no dorso da mão direita do seu componente do lado e assim em diante. 
Este movimento segue a silabação da música. O último a ser batido de acordo com a silabação da música sai da brincadeira. 